\title{
Biosaintifika
}

Journal of Biology \& Biology Education

http://journal.unnes.ac.id/nju/index.php/biosaintifika

\section{Optimization of In Vitro Conservation Protocol of Carica pubescens Lenne \& K. Koch through Medium Concentration, Temperature and Irradiation Duration Decrease}

\author{
${ }^{\circledR}$ Enni Suwarsi Rahayu, Noor Aini Habibah
}

DOI: 10.15294/biosaintifika.v8i1.5371

Department of Biology, Faculty of Mathematics and Science, Semarang State University, Indonesia.

\section{History Article}

Received 7 January 2016 Approved 23 February 2016

Published 29 March 2016

\section{Keywords:}

Carica pubescens, in vitro storage, irradiation duration, low concentration medium, low temperature

\begin{abstract}
Carica pubescens Lenne \& K. Koch, an endemic species in Dieng mountains, must be conserved. The in vitro conservation has been developed, but sub-culture period needs to be extended. This study aimed to obtain a more efficient in vitro conservation protocol of $C$. pubescens. The research was carried out experimentally by using a completely randomized factorial design with three factors, namely decreasing in storage medium concentration ( $75 \%$ and $50 \%$ of MS medium), temperature $\left(4^{\circ} \mathrm{C}\right.$ and $8^{\circ} \mathrm{C}$ ), and irradiation duration ( 8 hours/day and 16 hours/day). Shoots were kept in the storage medium for 6,9 and 12 months, then their viability were tested by growing them in the regeneration medium. Data were analyzed by Analyses of Variance and Least Significant Difference Test. The results showed that medium concentration of $50 \%$ of MS, the temperature of $8^{\circ} \mathrm{C}$, and 16 hours/day of irradiation were able to suppress the $C$. pubescens growth in vitro storage for six months and could maintain its viability in the regeneration medium. Based on these results the medium concentration of $50 \%$ of MS, the temperature of $8{ }^{\circ} \mathrm{C}$ and 16 hours/day irradiation can be used for in vitro conservation of $C$. pubescens without sub-culture for six months.
\end{abstract}

\section{How to Cite}

Rahayu, E., \& Habibah, N. (2016). Optimization of In Vitro Conservation Protocol of Carica pubescens Lenne \& K. Koch through Medium Concentration, Temperature and Irradiation Duration Decrease. Biosaintifika: Journal of Biology \& Biology Education, 8(1), 87-95.

(C) 2016 Semarang State University
Correspondence Author:

Sekaran Campus, Gunungpati, Semarang, Indonesia

E-mail: enni.bio@gmail.com
p-ISSN 2085-191X e-ISSN 2338-7610 


\section{INTRODUCTION}

Indonesia is a megadiversity country with plant genetic diversities of around 11,657 species, and 7,203 species are endemic that need to be preserved (ASEAN Center for Biodiversity, 2009). Plant germ plasm conservation can be carried out on land or in vitro culture. In in vitro plant conservation, plant materials are maintained in artificial medium and engineered physical environment. The in vitro conservation activity should be oriented towards the efficiency and effectiveness and maintain the plant materials viability without genetic structure changes when they are removed from the in vitro storage. The in vitro storage is conducted to plant that form recalcitrant seeds or do not form seeds (Kaviani, 2010).

Carica pubescens Lenne \& K. Koch is a typical flora from Wonosobo, Central of Java. It is endemic species in Dieng mountains so often called 'dieng papaja'. The fruit is fragrant and fresh with a chewy texture and has been widely used as raw material for some food and beverage industries. Due to very limited spreading, vulnerable to natural disasters and outbreaks of pests or diseases, this species needs to be conserved at outside of its natural habitat. In vitro storage is a suitable effort to preserve $C$. pubescens because it forms recalcitrant seeds.

There are several kinds of in vitro storage techniques, such as minimal growth technique that maintains plant materials in medium culture and physic environment conditions so that the growth rate is very small and does not need too frequent sub-cultures. To minimize the growth rate the medium is modified by decreasing the concentration of the nutrition or adding inhibitor and osmoregulator. It is also can be done through modifying culture physic environment by reducing the temperature, light intensity and duration of irradiation (Engelmann, 2011).

The result of the previous study showed that medium concentration decrease and osmoregulator addition may extend the sub-culture period of $C$. pubescens to 4 months. The medium concentrations decreases were $75 \%$ and $50 \%$ of the MS basic formulation, and osmoregulator addition was mannitol $20 \%$ added to $100 \%$ MS; incubated in $15 \pm 2{ }^{\circ} \mathrm{C}$ with 40 watt light for 24 hours/day continuously (Rahayu et al., 2015). The sub-culture period is expected to be extended by decreasing the concentration of medium combined with decreasing the physical environment, such as by setting temperature and duration of irradiation. The temperature of incubation room must be lowered below $15^{\circ} \mathrm{C}$. Storage tempera- ture of $10^{\circ} \mathrm{C}$ and $5{ }^{\circ} \mathrm{C}$ evidently successful for the preservation of Pyrus apical shoots (Ahmed et al., 2010). The duration of irradiation of in vitro conservation is generally lowered to 16,12 , and 8 hours/day. The period of 16 hours/day has proved useful in in vitro storage of some sugarcane cultivars (Ramanand \& Lal, 2004; Mishra, 2011) and potatoes (Gonzales \& Cueva, 2014; Al-Hussaini et al., 2015).

This study aimed to obtain a more efficient in vitro storage protocol of $C$. pubescent by determining the optimal reduction of the medium concentration, temperature and duration of irradiation. This effort is expected to result in the minimal growth of $C$. pubescens shoots with high viability.

\section{METHODS}

The main materials were $2 \mathrm{~cm}$ in vitro shoots with two leaves. The shoots were cultured from leaves explants obtained from dieng papaja tree grown at Dieng mountains. The research was experimentally done using a completely randomized factorial design with three factors, namely 1) the concentration of medium $[75 \%$ and $50 \%$ of Murashige \& Skoog (1962) or MS medium], 2) the temperature $\left(8^{\circ} \mathrm{C}\right.$ and $\left.4^{\circ} \mathrm{C}\right)$, and 3$)$ the duration of irradiation (16 hours/day and 8 hours/ day). Each treatment was done by ten times repeats.

The MS storage medium was made in a commonly way with the concentrations according to the treatments, i.e. $75 \%$ and $50 \%$ of the normal concentration; added by $2 \mathrm{ppm}$ benzene adenine (BA). The medium was poured into each culture bottle as much as $30 \mathrm{cc}$. The explant was planted aseptically in the culture bottles and then they were placed in the refrigerator. This research used four refrigerators with modified settings of temperature and duration of irradiation according to the treatment combinations, i.e. $8^{\circ} \mathrm{C}$ 16 hours, $8^{\circ} \mathrm{C}-8$ hours, $4^{\circ} \mathrm{C}-16$ hours, and $4^{\circ} \mathrm{C}-8$ hours. The irradiation was set with the white fluorescence lamp of 18 watts. The shoots were stored for three periods of time, namely 6, 9 and 12 months without sub-cultured.

The shoots stored in the medium for a certain period were then tested for viability. All of the shoots kept in the storage medium were transferred to the regeneration medium, i.e. MS $100 \%+2 \mu \mathrm{M}$ BA $+0.5 \mu \mathrm{M}$ indole butyric acid (IBA). After 3 weeks the shoots developed normally (with a length of more than $2 \mathrm{~cm}$ and has more than two opened leaves) were induced to form roots by maintaining in the medium MS + 
IBA $17.5 \mu \mathrm{M}$ for 4 days and then transferred to an MS medium without growth regulators.

The research variables observed were the shoot growth in the storage medium and shoot viability in the regenerating and rooting medium. The shoot growth measured included the percentage of survived shoots, the number of shoots/ explant, the number of leaves/shoot, and shoot morphology. The shoots morphology parameter observed was the intensity of chlorosis and necrosis shown in the scores. Symptoms of chlorosis $0-10 \%$ (4), symptoms of chlorosis $11-30 \%$ (3), symptoms of chlorosis $31-60 \%$ and/or accompanied symptoms of necrosis (2), and chlorosis symptoms $>60 \%$ and accompanied by symptoms of necrosis (1). The viability variables included the percentage of survived shoots, an increase of the number of leaves/shoot, the percentage of shoots forming roots, the number of roots/shoot and root length. In addition, it was also observed morphological plantlets such as chlorosis, necrosis, and succulence.

The quantitative data were analyzed by using three factors Analysis of Variance (ANOVA) and Least Significant Difference (LSD) test by using SPSS statistical analysis program. The qualitative data were analyzed descriptively.

\section{RESULTS AND DISCUSSION}

\section{The shoot growth in the in vitro storage}

The percentage of survived shoots in various combinations of treatments on the storage period of 6 months ranged between $80 \%-100 \%$, and decreased significantly (30-40\%) during 9 months
(Table 1, Fig. 1a). Shoots stored for six months grew normally, leaves multiplied with green colour or slightly chlorotic (Fig. 2 a-h), while shoots stored for nine months seem suffered from severe chlorosis (Fig. 2 i-j), and none of the shoots survived when stored for 12 months.

The ANOVA showed that medium concentration and duration of irradiation separately had significantly effected on the number of shoots/explant. The explants stored in 50\% of MS medium produced new shoots less than that stored in $75 \%$ of MS (Table 1, Fig. 1b). After being stored for nine months, the number of shoots did not significantly increase than that being stored for six months on all treatments (Fig. 1b). There were no significant differences in the average number of shoots produced between the treatments of temperatures and the irradiation durations in storage on $50 \%$ of MS medium (Table 1).

Results of ANOVA indicated that the medium concentration and duration of irradiation separately influenced the number of leaves/ shoot. The average number of leaves formed in medium MS 50\% was less than that formed in medium MS $75 \%$, as well as in the duration of irradiation of 8 hours was less than 16 hours (Fig. 1c). Interaction of nutrient concentrations, temperature and duration of irradiation also affected the number of leaves/shoots. The lowest number of leaves/shoot was achieved at 8 hours irradiation period, both at a temperature of $8^{\circ} \mathrm{C}$ and $4^{\circ} \mathrm{C}$ (Table 1).

Based on ANOVA results, the shoots morphology was significantly influenced only by the

Table 1. The shoots growth in various in-vitro storage conditions during six months

\begin{tabular}{|c|c|c|c|c|c|}
\hline \multirow{4}{*}{$\begin{array}{l}\text { Growth } \\
\text { parameters }\end{array}$} & \multirow{4}{*}{$\begin{array}{l}\text { Nutrition } \\
\text { concentration } \\
\text { (\% MS) }\end{array}$} & \multicolumn{4}{|c|}{ Temperature $\left({ }^{\circ} \mathrm{C}\right)$} \\
\hline & & \multicolumn{2}{|c|}{8} & \multicolumn{2}{|c|}{4} \\
\hline & & \multicolumn{2}{|c|}{ Irradiation duration (hour) } & \multicolumn{2}{|c|}{ Irradiation duration (hour) } \\
\hline & & 16 & 8 & 16 & 8 \\
\hline \multirow{2}{*}{$\begin{array}{l}\text { Percentage of } \\
\text { survived shoots }\end{array}$} & 75 & $100 \mathrm{a}$ & $80 \mathrm{~b}$ & $100 \mathrm{~b}$ & $80 \mathrm{~b}$ \\
\hline & 50 & $90 \mathrm{ab}$ & $80 \mathrm{~b}$ & $90 \mathrm{ab}$ & $80 \mathrm{~b}$ \\
\hline \multirow{2}{*}{$\begin{array}{l}\text { Number of } \\
\text { shoots/ } \\
\text { Explant }\end{array}$} & 75 & $5.40 \mathrm{a}$ & $4.40 \mathrm{~b}$ & $6.00 \mathrm{a}$ & $4.20 \mathrm{~b}$ \\
\hline & 50 & $1.70 \mathrm{c}$ & $1.90 \mathrm{c}$ & $1.40 \mathrm{c}$ & $1.30 \mathrm{c}$ \\
\hline \multirow{2}{*}{$\begin{array}{l}\text { Number of } \\
\text { leaves/ } \\
\text { Shoot }\end{array}$} & 75 & $2.45 \mathrm{~b}$ & $2.21 \mathrm{c}$ & $2.61 \mathrm{a}$ & $2.18 \mathrm{~cd}$ \\
\hline & 50 & $2.24 \mathrm{c}$ & $2.08 \mathrm{~d}$ & $2.25 \mathrm{c}$ & $2.00 \mathrm{~d}$ \\
\hline \multirow{2}{*}{$\begin{array}{l}\text { Morphology } \\
\text { score }\end{array}$} & 75 & $3.90 \mathrm{a}$ & $3.10 \mathrm{bc}$ & $3.70 \mathrm{a}$ & $3.10 \mathrm{bc}$ \\
\hline & 50 & $3.50 \mathrm{ab}$ & $2.70 \mathrm{c}$ & $3.30 \mathrm{~b}$ & $2.80 \mathrm{c}$ \\
\hline
\end{tabular}

Notes: The score in the same parameter followed by different letters means significantly different based on the LSD test $5 \%$ 
duration of irradiation. In the 8 hours irradiation duration, the leaf morphology scores were lower than that of the 16 hours irradiation duration (Table 1, Fig. 1d). The lower score was characterized by the occurrence of chlorosis (Fig. 2b, 2d, 2f, $2 \mathrm{~h})$. Otherwise the higher score was marked with normal pigmentations and textures (Figure $2 \mathrm{a}$, $2 \mathrm{c}, 2 \mathrm{e}, 2 \mathrm{~g})$. On the all of the treatments, shoots
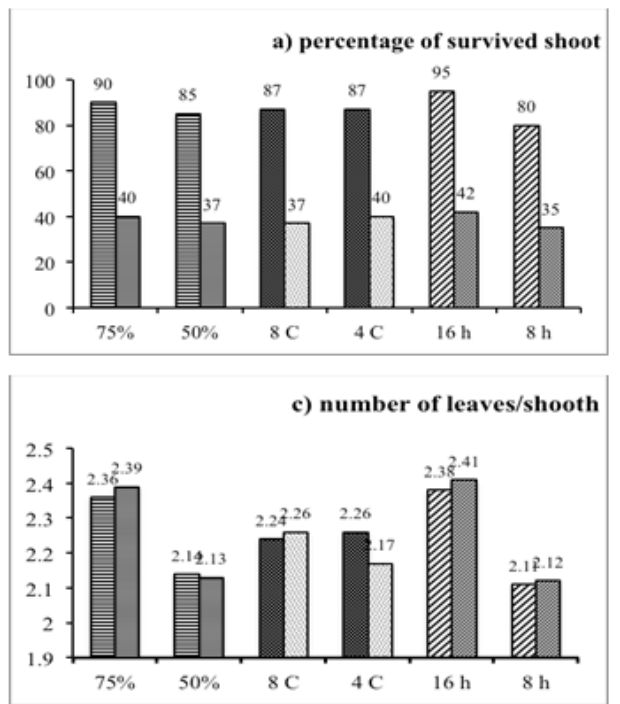

morphology stored for nine months decreased significantly compared to the storage period of 6 months (Table 1, Fig. 1d), which was characterized by severe chlorosis (Fig. 2i), even there were some whitened shoots with a soft texture (Fig. $2 \mathrm{j}$ ). Therefore, we tested shoots viability derived from the storage period of 6 months.
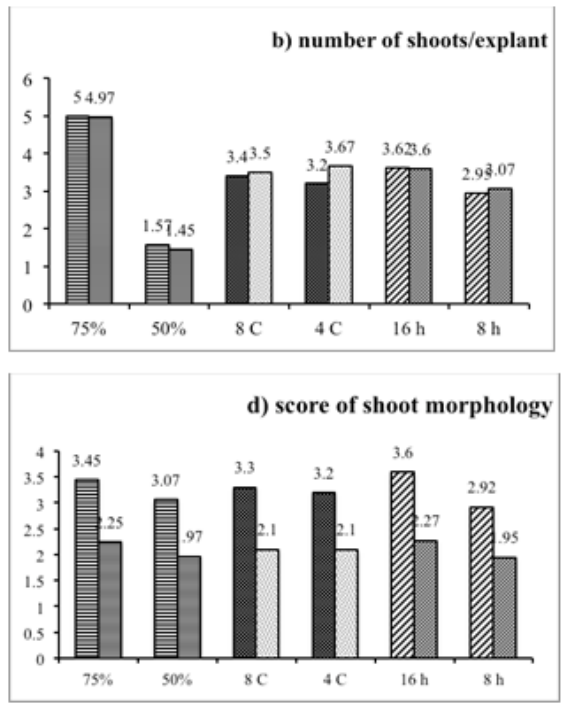

Figure 1. The average of survived shoots percentage, number of shoots/explant, number of leaves/ shoot, and shoot morphology score during the storage period of 6 months (left) and 9 months (right) in the treatment of medium concentration reduction $(75 \%$ and $50 \%)$, storage temperature $\left(8^{\circ} \mathrm{C}\right.$ and $4^{\circ} \mathrm{C}$ ) and the duration of irradiation (16 hours and 8 hours)
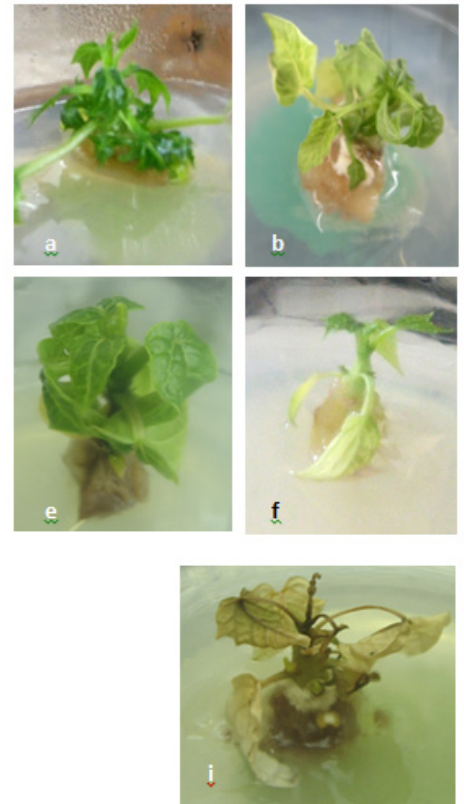
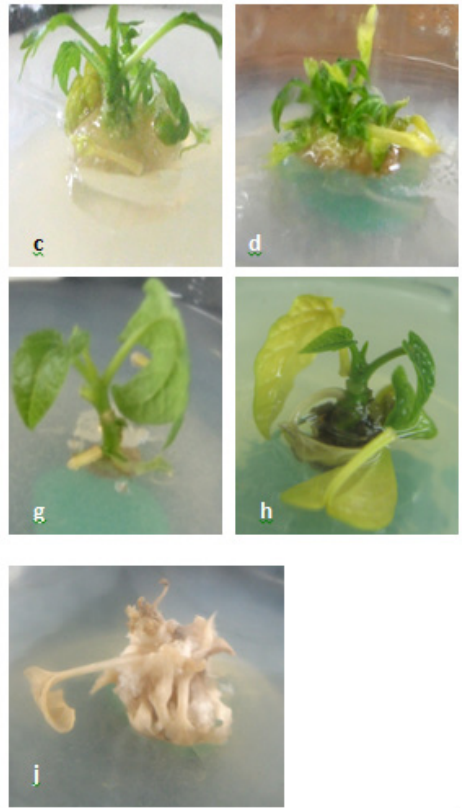

Figure 2. The performance of C. pubescens shoots after stored in various treatments. Shoot performance after stored for 6 months in the in-vitro storage medium concentration, temperature and irradiation duration of a) $75 \% \mathrm{MS}, 8^{\circ} \mathrm{C}$ and 16 hours, b) $75 \% \mathrm{MS}, 8^{\circ} \mathrm{C}$, and 8 hours, c) $75 \% \mathrm{MS}, 4^{\circ} \mathrm{C}$ and 16 hours, d) $75 \% \mathrm{MS}, 4^{\circ} \mathrm{C}$ and 8 hours, e) $50 \% \mathrm{MS}, 8^{\circ} \mathrm{C}$ and 16 hours, f) $50 \% \mathrm{MS}, 8^{\circ} \mathrm{C}$ and 8 hours, g) $50 \% \mathrm{MS}, 4{ }^{\circ} \mathrm{C}$ and 16 hours, h) $50 \% \mathrm{MS}$, and $4{ }^{\circ} \mathrm{C}$ and 8 hours; and i) and j) shoot had been maintained for 9 months. 
The shoot viability after in vitro storage for six months

Having been removed from the storage medium and transferred to the recovery medium, $100 \%$ of shoots maintained in various storage treatments could survive (Table 2) with normal morphology without chlorosis or necrosis. The shoots previously stored at $8^{\circ} \mathrm{C}$ were capable of forming new leaves most than the other treatments (Fig. 3a). The highest increase of leaves/ shoot happened on the shoots maintained in the concentration of $50 \%, 8^{\circ} \mathrm{C}$ temperature and 8 hours duration of irradiation (Table 2), but they did not form roots (Fig. 4a).

In general, the shoots stored in 16-hour irradiation had the highest ability to form roots after storage period (Fig. 3b). The number of shoots that form roots of $87.5-100 \%$ were achieved by shoots stored in the 16-hour duration of irradiation, both at nutrition concentration of $75 \%$ and $50 \%$ and temperature of $4^{\circ} \mathrm{C}$ and $8^{\circ} \mathrm{C}$. Shoots maintained in the 8 hours duration of irradiation formed roots lower (0-50\%) than that stored in the 16 hours (Table 2).

The shoots stored at $4^{\circ} \mathrm{C}$ were capable of forming roots at most when they were recovered (Fig. 3c). The highest number of roots/shoot was achieved by shoot maintained at $75 \%$ medium concentration, $8^{\circ} \mathrm{C}$ temperature and 16 hours duration of irradiation (Table 2, Figure $4 \mathrm{~b}$ ) and $4^{\circ} \mathrm{C}$ temperature and 8 hours irradiation duration (Fig. 4c). The shoots stored at $4^{\circ} \mathrm{C}$ and 16 hours irradiation duration were capable of generating the longest roots when they were recovered (Fig. 3d). The longest roots were showed in the shoots previously stored at temperatures of $8^{\circ} \mathrm{C}$ with 16 hours of irradiation duration, both in the medium concentration of $75 \%$ (Table 2, Fig. 4c) and $50 \%$ (Table 2, Fig. 4d).

The optimal in vitro conservation protocol was the culture conditions resulted in the minimal growth during the storage and relatively viable during recovery. Based on these findings, $50 \%$ MS medium concentration, $8^{\circ} \mathrm{C}$ temperature and 16 hours irradiation duration were the optimum treatment for in vitro conservation of $C$. pubescens shoots because these conditions resulted in the relatively small growth of shoots (1.7 shoots/ explant) and leaves (2.24 leaves/shoot) and fairly good morphology (score of 3.5) during the period of storage; and during the recovery period 100 $\%$ of shoots survived, formed 3 leaves/shoot, $100 \%$ of shoots formed roots with $4.8 \mathrm{~cm}$ of root length, although only 2.6 roots/shoot. The me-

Table 2. The viability of shoots stored during six months in various in-vitro storage conditions

\begin{tabular}{|c|c|c|c|c|c|}
\hline \multirow{4}{*}{ Viability parameter } & \multirow{4}{*}{$\begin{array}{l}\text { Nutrition } \\
\text { concentra- } \\
\text { tion } \\
(\% \mathrm{MS})\end{array}$} & \multicolumn{4}{|c|}{ Temperature $\left({ }^{\circ} \mathrm{C}\right)$} \\
\hline & & \multirow{2}{*}{\multicolumn{2}{|c|}{$\begin{array}{c}8 \\
\begin{array}{c}\text { Irradiation duration } \\
\text { (hours) }\end{array}\end{array}$}} & \multirow{2}{*}{\multicolumn{2}{|c|}{$\begin{array}{c}4 \\
\begin{array}{c}\text { Irradiation duration } \\
\text { (hours) }\end{array}\end{array}$}} \\
\hline & & & & & \\
\hline & & 16 & 8 & 16 & 8 \\
\hline \multicolumn{6}{|c|}{ Survived shoots percentage } \\
\hline & 75 & 100 & 100 & 100 & 100 \\
\hline & 50 & 100 & 100 & 100 & 100 \\
\hline \multicolumn{6}{|c|}{ Increase of leaves/shoots } \\
\hline number & 75 & $2.8 \mathrm{~b}$ & $1.3 \mathrm{~d}$ & $3.2 \mathrm{~b}$ & $1.3 \mathrm{~d}$ \\
\hline & 50 & $3.0 \mathrm{~b}$ & $5.1 \mathrm{a}$ & $2.3 \mathrm{c}$ & $1.7 \mathrm{~cd}$ \\
\hline \multicolumn{6}{|c|}{ Root-formed shoots percentage } \\
\hline & 75 & $100 \mathrm{a}$ & $50.0 \mathrm{~b}$ & $87.5 \mathrm{a}$ & $37.5 \mathrm{bc}$ \\
\hline & 50 & $100 \mathrm{a}$ & $0.0 \mathrm{~d}$ & $87.5 \mathrm{a}$ & $25.0 \mathrm{c}$ \\
\hline \multicolumn{6}{|c|}{ Number of roots/shoot } \\
\hline & 75 & $6,6 \mathrm{a}$ & $3.0 \mathrm{~b}$ & $2,4 b$ & $7,2 \mathrm{a}$ \\
\hline & 50 & $2.6 \mathrm{~b}$ & $0.0 \mathrm{c}$ & $1.4 \mathrm{c}$ & $1.2 \mathrm{c}$ \\
\hline \multicolumn{6}{|l|}{ Roots length } \\
\hline & 75 & $5.2 \mathrm{a}$ & $4.0 \mathrm{~b}$ & $3.3 \mathrm{~b}$ & $1.4 \mathrm{c}$ \\
\hline & 50 & $4.8 \mathrm{a}$ & $0.0 \mathrm{c}$ & $1.0 \mathrm{c}$ & $0.8 \mathrm{c}$ \\
\hline
\end{tabular}

Notes: The scores in the same parameter followed with different letters means significantly different based on the LSD $5 \%$ test 

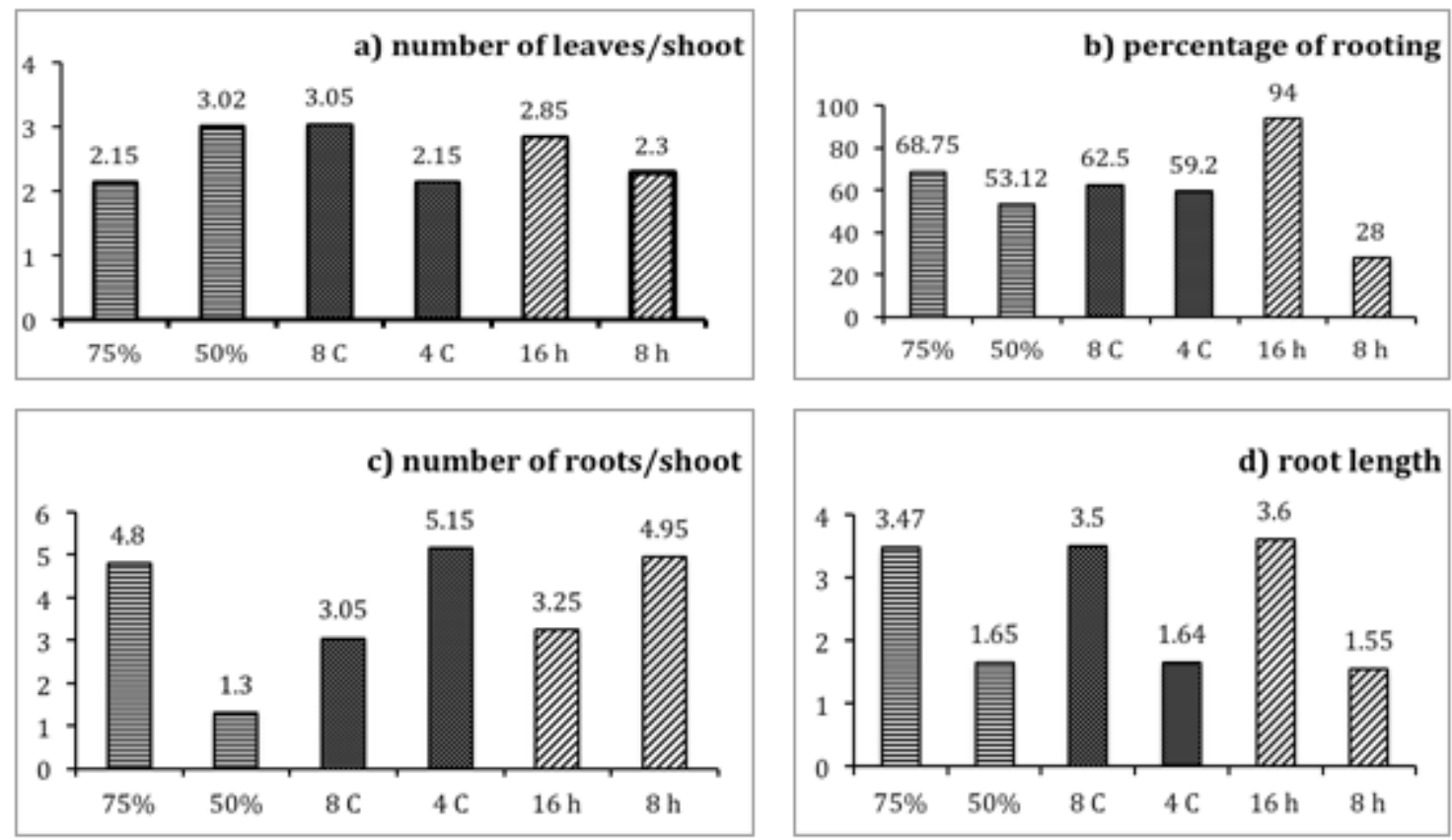

Figure 3. The number average of leaves/shoots, rooting percentage, number of roots/shoots and roots during the long storage period of 6 months on nutrient concentration reduction treatment $(75 \%$ and $50 \%)$, storage temperature $\left(8^{\circ} \mathrm{C}\right.$ and $\left.4^{\circ} \mathrm{C}\right)$ and the duration of irradiation (16 hours and 8 hours)
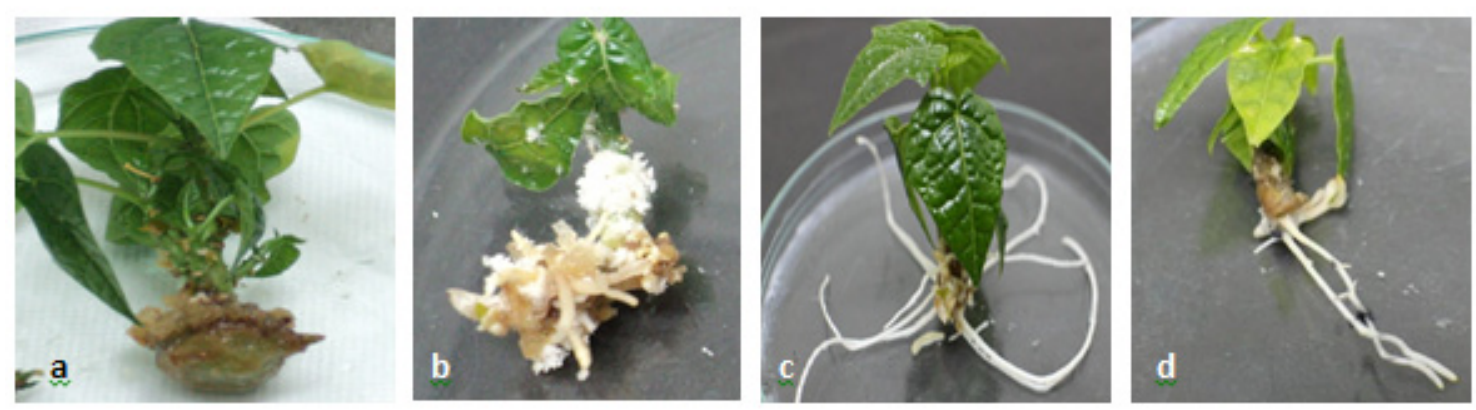

Figure 4. The plantlet performance after recovering from the storage of a) 50\% MS medium, $8^{\circ} \mathrm{C}$ temperature and 8 hours irradiation duration, b) $75 \%$ MS medium, $8^{\circ} \mathrm{C}$ temperature, and 16 hours irradiation duration, c) $75 \%$ of MS medium, $4^{\circ} \mathrm{C}$ and 8 hours irradiation period, and d) $50 \%$ MS medium, $4^{\circ} \mathrm{C}$ temperature and 8 hours irradiation duration

dium of $50 \%$ MS with 16 hours irradiation duration and $4^{\circ} \mathrm{C}$ temperature was able to suppress the growth of shoots, but during the recovery period, the viability was lower than that the treatment combination above.

The results indicated that the nutrient concentration, temperature and irradiation duration affected the intensity of growth and development. Plant growth and development in vitro culture, especially in organogenesis pathway, takes place through the formation of new organs directly from explants through 1) induction of cell division, 2) formation of meristemoid tissue, namely certain zones in the explant contain actively dividing cells, and 3 ) development of organs from meristemoid tissue. These steps require nutrients, enzymes, energy, and hormones (Ramage and William, 2002). In this experiment, the explants ability maintaining a normal morphology at $50 \%$ medium concentration showed that the nutrient content in the medium adequately provided growth and development despite of the intensity of growth relatively low. This result was in line with the research finding on Elettaria cardamomum Maton (Tyagi et al., 2009) and Smallanthus sonchifolius (Skalova et al., 2012). If the nutrient concentration of conservation medium is not lowered, the growth rate of explants will be relatively high and hence needed frequent subculturing. It is not efficient in vitro conservation 
activities (Engelmann, 2011).

Temperature determines the kinetic energy of organic molecules (such as protein component of enzymes), their collision and reaction rates; the strength of the interaction of molecules; and other physic-chemical properties. Therefore, temperature affects the activity of enzymes that controll all of the biochemical activities, such as synthesis of chlorophyll (Carter \& Knapp, 2001); size and shape of photosynthetic cells, amount of pigments, and consequently photosynthesis itself (Georgieva \& Lichtenthaler, 2006); absorption of water and nutrients as well as respiration in order to produce energy (Taiz \& Zeiger, 2010). Plants have an optional temperature range at which they function best. There is a positive relationship between the temperature of plant habitat and the temperatures of optimal activity of their enzymes. In a low temperature, the enzyme isolated from plants living in low-temperature area would have maximum activity because its configuration is stable, while when isolated from plants derived from a high-temperature area it would be labile and declining its activity (Elias et al., 2013). For example, the optimal temperature range of peanut growth is $22-280 \mathrm{C}$. Their embryogenic calli incubated in culture room with a temperature of $25^{\circ} \mathrm{C}$ during the day and night can optimally proliferated and regenerated to form normal plantlets (Rahayu \& Sudarsono, 2015). This indicates that at the optimal temperature range the enzymes of the peanut calli active with adequate rate and causing metabolism, growth, and development.

Light is an important factor of plant life. In addition to being required for photosynthesis, light also affects many key events in plant growth and development. The effects of light on plant metabolism are based on its quality, intensity and duration. The length of irradiation of light influences the metabolism intensity and direction of development. It is received by some photoreceptors that convert the inactive into active forms of the chemical compound. This mechanism affects the level change of endogenous hormones or other physiological components that enabled growth and development (Taiz \& Zeiger, 2010). The optimal range of duration of irradiation was specific to each species. Out of the optimal range, the duration of irradiation would decrease the growth and development.

The protocol of in vitro storage through medium concentration reduction, temperature and duration of irradiation developed in this study were in line with other several studies before. The mint species that was tolerant to cold tempe- ratures can be stored in medium MS 50\%, with a 12-hour irradiation and temperature of $4^{\circ} \mathrm{C}$ for 24-36 months (Reed, 1999). Bekheet (2000) reported that the storage of Asparagus officinalis was successfully managed at $5^{\circ} \mathrm{C}$ in the dark, and $100 \%$ of plantlets were able to regenerate after being stored for 6 months. Melia azedarach apical buds could be stored efficiently without subculture for 12 months at $4^{\circ} \mathrm{C}$ in $1 / 4$ MS medium (Scocchi \& Mroginski, 2004). The apical buds of Vetiveria zizanioides Nash 'Songkla 3' were stored in $25 \%$ of MS medium added with paclobutrazol $3 \mathrm{mg} / 1$ in the 14-hour irradiation with the temperature of $27 \pm 1^{\circ} \mathrm{C}$ for 12 months. The buds were able to maintain viability well after being transferred to regeneration medium (Moosikapala \& Te-chato, 2010).

Furthermore, in vitro conservation protocol were developed on 16 of the endangered cactus species/sub-species Turbinicarpus. The growth of shoots stored at four $\pm 0.5^{\circ} \mathrm{C}$ was reduced but the viability after 12 months storage period could still be maintained. When returned to the recovery medium containing cytokines, the shoots capable of regenerating roots and producingwere survived plantlet in the land (Pérez-MolpheBalch et al., 2012).

Lopez-Puc (2013) found a storage protocol of Epidendrum chlorocorymbos Schltr, namely the medium MS $50 \%$ added by $1 \%$ sorbitol with lighting 16 hours/day, the temperature of $23 \pm$ $2{ }^{\circ} \mathrm{C}$ and relative humidity of $50-80 \%$. In these conditions, the explants stored for six months grew slowly with remained normal morphology. In the medium recovery (MS $100 \%$ without PGR) shoots were able to grow and develop into perfect plantlets (Lopez-Puc, 2013). The identical storage protocol was also suitable for banana $\mathrm{cv}$. Dwarf Cavendish, namely the medium MS of $50 \%$ and a temperature of $15^{\circ} \mathrm{C}$ (Tokoporo et al., 2013), while the minimal growth in the preservation of in-vitro date palm 'zaghlool' achieved at a temperature of $5^{\circ} \mathrm{C}$ (El-Dawayati et al., 2013).

The optimal concentration of storage medium for Glycyrrhiza glabra was $25 \%$ to ensure the explants remained viable for eight months as much as $60 \%$ of explants were maintained without change regeneration potential (Uzundzhalieva et al., 2014). Sweet potato genotypes IPB IPB-072 and 137 could be kept for 3 and six months, respectively, in MS medium without ABA at $18{ }^{\circ} \mathrm{C}$. The genotypes IPB-052 and IPB072 was possible to store for six months and IPB007 and IPB-137 for nine months using $30 \mathrm{~g} / 1$ of sucrose and $50 \%$ of MS salts (Arigoni-Blank et al., 2014). 
This research successfully produced an efficient shoots storage protocol of $C$. pubescens with longer time intervals ( 6 months) through storing the shoot in a medium of $50 \%$ MS under a temperature of $8^{\circ} \mathrm{C}$, and 16-hour/day irradiation. It was better than the results of the previous study that the optimal sub-culture period was 4 months only through decreasing the medium concentration to $75 \%$ and $50 \%$ of the MS basic formulation, or $100 \%$ MS supplemented with mannitol $20 \%$, incubated in $15 \pm 2{ }^{\circ} \mathrm{C}$ with 40 watt light for 24 hours continuously (Rahayu et al., 2015). Therefore, the present result did not only save energy and costs because used lower irradiation duration and did not use mannitol; but also prevented negative effects on the genetic structure, such as somaclonal variation due to the too often sub-culture. The results showed that the decrease in the concentration of the medium, temperature and duration of the irradiation was effective for the in vitro C. pubescens storage for six months though it was not effective yet for the storage of 9 months or more. This needs to be studied further to find a protocol that can extend the storage period, for example by adding some growth inhibitors.

\section{CONCLUSION}

It could be concluded that the decrease in the concentration of $50 \% \mathrm{MS}$ medium, the temperature of $8^{\circ} \mathrm{C}$, and a 16 -hour irradiation was capable of reducing the growth of $C$. pubescens in the in vitro storage for six months, and maintain its viability after being restored in the regeneration medium. Based on these results it was recommended that the protocol can be used to save the C. pubescens shoots for six months without doing sub-culture. With this protocol, it was possible to maintain a bank of $C$. pubescens shoots with minimal maintenance, and whenever required it was possible to obtain normal plantlets.

\section{ACKNOWLEDGMENT}

The authors would like to thank to General Directorate of Higher Education, Ministry of National Education, Republic of Indonesia for funding the part of this research through the competitive research grants. The further research was done using the own funding. Gratefulness is also addressed to for Aida Raisa Amalia, S.Si for her great contribution to this research.

\section{REFERENCES}

Ahmed, M., Anjum, M.A., Shah, A.H., \& Hamid, A. (2010). In Vitro preservation of Pyrus germplasm with minimal growth using different temperature regimes. Pak. J. Bot., 42(3), 16391650.

Al-Hussaini, Z. A, Yousif, S. H., \& AL-Ajeely, S. A. (2015). The role of sucrose and light duration on in vitro tuberization for two cultivars of potato Solanum tuberosum L. Int. J. Curr. Microbiol. App. Sci. 4(2), 277-283.

Arrigoni-Blank, M.F., Tavares, F.F., Blank, A.F., Santos, M.C., Menezes, T.S.A., \& de Santana, A.D.D. (2014). In Vitro Conservation of Sweet Potato Genotypes. The Scientific World Journal, article ID 208506, 7 pages. http://dx.doi. org/10.1155/2014/208506

ASEAN Centre for Biodiversity (2009). ASEAN Centre for Biodiversity: Conserving and managing biodiversity at the regional level. First ASIA-HORCS Joint Symposium. Nagoya, Japan:18-20 July 2009.

Bekheet, S. A. (2000). In vitro preservation of Asparagus officinalis. Biol. Plant, 43(2), 179-183.

Carter, G. A. \& Knapp, A. K. (2001). Leaf optical properties in higher plants: linking spectral characteristics to stress and chlorophyll concentration. Am. J. of Botany, 88(4), 677-684.

El-Dawayati, M., Maiada, E. I., Baker, A. H., Gomaa, \& Zayed, Z. E. (2013). In vitro conservation of date palm shoot tip explants under minimal growth condition. Egypt. J. Agric. Res. 91(3), 1043-1061.

Elias, M., Wieczorek, G., Rosenne, S., \& Tawfik, D. S. (2014). The universality of enzymatic ratetemperature dependency. Trends in Biochem. Sci. 39(1), 1-7.

Engelmann, F. (2011). Use of biotechnologies for the conservation of plant biodiversity. In Vitro Cell. Dev. Biol. Plant, 47(1), 5-16.

Georgieva, K. \& Lichtenthaler, H. K. (2006). Photosynthetic response of different pea cultivars to low and high temperature treatments. Photosynthetica, 44(4), 569-578.

González, Y. \& Cueva, A. (2014). Effects of photoperiod, plant growth regulators and culture media on in vitro growth of seedlings of Cyrtochilum loxense (Lind1.) Kraenzl. An endemic and endangered orchid from Ecuador. Revista Peruana de Biología, 21(2), 189-192.

Kaviani, B. (2010). Conservation of plant genetic resources by cryopreservation. Aust. J. of Crop Sci. 5(6), 778-800.

Lopez-Puc, G. (2013). An effective in vitro slow growth protocol for conservation of the orchid 
Epidendrum chlorocorymbos Schltr. Tropical and Subtropical Agroecosystems, 16(1), 61 - 68.

Mishra, S. (2011). Effect of temperature, photoperiod and ph on in vitro shoot multiplication of sugarcane. Vegetos, 24(1), 50-53.

Moosikapala, L., \& Te-chato, S. (2010). Application of in vitro conservation in Vetiveria zizanioides Nash. J. Agric. Technol, 6(2), 401-407.

Murashige, T., \& Skoog, F. (1962). A revised medium for rapid growth and bioassays with tobacco tissue culture. Physiol. Plant, 15(3), 473-497.

Pérez-Molphe-Balch, E., Pérez-Reyes, M.E., \& RosaCarrill, D.L. (2012). In vitro conservation of Turbinicarpus (Cactaceae) under slow growth conditions. Haseltonia, 17, 51-57.

Rahayu, E. S., Aini, N. A., \& Herlina, L. (2015). In vitro conservation medium of Carica pubescens Lenne \& K. Koch by nutrients concentration reduction and osmoregulator addition. Biosaintifika: Journal of Biology \& Biology Education, 7(1), 24-30.

Rahayu, E. S., \& Sudarsono. (2015). In-vitro selection of drought tolerant peanut embryogenic calli on medium containing polyethylene glycol and regeneration of drought tolerant plants. Emir. J. Food Agric, 27(6), 475-487.

Ramanand \& Lal, M. (2004). An efficient protocol for in vitro micropropagation of sugarcane. Sugar Tech, 6 (1\&2), 85-87.
Ramage, C. M. \& Williams, R. R. (2002). Mineral nutrition and plant morphogenesis. In vitro Cell. Dev. Biol. Plant, 38(2), 116-124.

Reed, B. M. (1999). In vitro storage conditions for mint germplasm. Hortsci. 34(2), 350-352.

Scocchi, A. M., \& Mroginski, L. A. (2004). In vitro conservation of apical meristem-tip of Melia azedarach L. (Meliaceae) under slow-growth conditions. Phyton (B. Aires), 73, 137-143.

Skalova, I., Viehmannova, I., \& Vitamvas, J. (2012). In vitro conservation of Smallanthus sonchifolius under slow-growth conditions. Agric. Tropica et Subtropica, 45(3), 147-150.

Taiz, L. \& Zeiger, E. (2010). Plant Physiology. Massachussets: Sinauer Associated Inc.Publishers.

Tokoporo, G.L., Elhassan, A.A., \& Ali, M.A. (2013). Effect of nutrient medium concentration and temperature on short-term in vitro conservation of shoot-tip explants of banana. Jonares 1, 37-40.

Tyagi, R.K., Goswami R., Sanayaima R., Singh R., Tandon R., \& Agrawal, A. (2009). Micropropagation and slow growth conservation of cardamom (Elettaria cardamomum Maton). In Vitro Cell. Dev. Biol. Plant, 45(6), 721-729.

Uzundzhalieva, K., Ruseva, R., \& Kachakova, S. (2014). Ex Situ and In Vitro Conservation of Glicyrrhiza glabra L. - Crop Wild Relative from Fabaceae. Ecologia Balkanica 5, 9-13. 